\title{
Revisiting the Manila Galleon, a Chilean Perspective from the XXI Century
}

\author{
Juan Pablo Glasinovic Vernon*
}

\begin{abstract}
The Manila Galleon marked the beginning of globalization as we know it today, linking Asia with the Americas and Europe through trade, from the second half of the XVI century until the first decades of the XIX century. Only a few decades after its discovery and conquest by Spain, the American continent burst onto the global scene allowing quasi industrial production in China and global trade, based on the silver pattern. A combination of circumstances made possible this first wave of globalization, ignited by the Americas. Looking back at that experience, we can better understand the current status of world affairs and extract some important lessons for Latin America in order to recover prominence in the relationship with Asia.
\end{abstract}

Keywords: Manila Galleon, global trade networks, Spanish empire, colonial trade, Chile.

\section{Resumen}

El Galeón de Manila marcó el comienzo de la globalización tal como la conocemos hoy, vinculando, a través del comercio, a Asia con América y Europa, desde la segunda mitad del siglo XVI hasta las primeras décadas del siglo XIX. Solo unas pocas décadas después de su descubrimiento y conquista por parte de España, el continente americano irrumpió en la escena global permitiendo una producción casi industrial en China y un comercio global, basado en el patrón de plata. Una combinación de circunstancias hizo posible esta primera ola de globalización, encendida por las Américas. Mirando hacia atrás a esa experiencia, podemos entender mejor el estado actual de los asuntos mundiales y extraer algunas lecciones importantes para América Latina a fin de recuperar prominencia en la relación con Asia.

Palabras claves: Galeón de Manila, redes de comercio global, imperio español, comercio colonial, Chile.

\footnotetext{
* Lawyer, Pontifical Catholic University of Chile, MA in Political Science and International Relations; Master of Arts in Area Studies (South East Asia), University of London. Email: jpglasinovic@gmail.com. Received: December, 3rd 2018; accepted: January, 23rd 2019.
} 
Juan Pablo Glasinovic Vernon

Revisting the Manila Galleon, a Chilean perspective from the XXI century

\section{Introduction}

The purpose of this article is to review what constituted the first global trade network: the Manila Galleon. As we shall see, trade between Asia, the Americas and Europe, leveraged on American silver, stimulating a great production of goods, mostly silk and porcelain, mainly in China. This in turn had important consequences and ramifications of all kind, worldwide and regionally. Despite its length and effects, most of these consequences have not been studied nor sufficiently addressed and analyzed. Therefore, this article pretends to be a small contribution in order to decrease the knowledge gap, but most importantly, to draw to attention to this subject which is little known for the average people in the Americas and East Asia, despite its importance.

For two and a half centuries, the Americas became the axis of commerce between Asia and Europe, and that is not an issue to be ignored. In the following pages, mainly from a historical perspective, we will review the conditions that sustained this exchange and its development. In that process, we will also briefly describe how Chile is related to this topic. Although Chile was never an important player in this trade scheme, it benefitted from the increase of regional wealth based on international exchanges. Chile, a remote and deficitary Spanish colony was incorporated into the global trade, as a consequence of a wider movement pulled by the Manila Galleon.

In order to conclude, we will reflect on the legacy and some lessons that can be drawn from this historical experience, and their projection for the current relationship between Latin America and Asia, especially with China.

\section{The Beginning of the Story: Spices and European Naval Development}

To understand the Manila Galleon and its impact on global trade, we must look at the precedents and the conditions that made it possible for several centuries. The trade of spices was central to this development and the exchange existed long before the foundation of Rome, in a permanent flow of merchandises (including of course silk) from East Asia to Europe.

For many centuries, and until the XVI century, Europe was at the far end of the trading chain for spices, intermediated by Arab merchants mainly, without the power to contest exorbitant prices. At one point in the 1300s, a pound of nutmeg in Europe cost seven fattened oxen and was more valuable than gold (Munro, 1983). After protracted wars with other direct competitors in the Mediterranean (finally defeating her harshest rival, Genoa), Venice became the main distributor of spices in Europe and owed its prosperity and influence on that intermediation. By the 1400s, when navigational equipment had improved to the point that long-haul sailing became possible, the monarchs of Europe set out to change the balance of world trade by funding spice-hunting missions of their own.

The subsequent race to reach the sources of the spices had some well-known milestones: Christopher Columbus, commissioned by the Spanish Crown, who, in search of a quicker route to the spice's islands, bumped into the American continent instead. On behalf of the Portuguese, Vasco da Gama was the first to round Africa, and a flotilla led by Ferdinand Magellan, Portuguese at the service of Spain, circumnavigated the globe (although he died on the journey), opening the route that Columbus was 
looking for. Spain and Portugal, the ascending powers in Europe and leaders in naval technique and exploration at the time, requested the papal intervention to avoid a collision course in their frantic search of a maritime route to the spices area. The pressure increased after Columbus' discoveries and the possibility to have Portugal and other states as claimants of these new lands.

In 1493, Alexander VI (Spanish born pope) issued bulls setting up a line of demarcation from pole to pole 100 leagues (about 320 miles) west of the Cape Verde Islands. Spain was given exclusive rights to all newly discovered and undiscovered lands in the region west of the line. Portuguese expeditions were kept to the east of the line. Neither of them was supposed to occupy any territory already in the hands of the other. This was ratified by the Treaty of Tordesillas (June 7, 1494), agreement between the two powers aimed at settling conflicts over lands newly discovered.

The line itself was moved to 370 leagues (1,185 miles) west of the Cape Verde Islands, or about $46^{\circ} 30^{\prime} \mathrm{W}$ of Greenwich. Pope Julius II finally sanctioned the change in 1506. The new boundary enabled Portugal to claim the coast of Brazil after its discovery by Pedro Álvares Cabral in 1500. In 1524, due to unresolved differences of interpretation and the ongoing competition to reach East Asia, both kingdoms, Spain (Charles I) and Portugal (John III) organized the "Junta de Badajoz-Elvas" to resolve the dispute. The intention was to divide the whole world into two equal hemispheres, establishing the exact location of the antemeridian of Tordesillas.

The Treaty of Zaragoza laid down that the eastern border between the two domain zones was 297.5 leagues (1,763 kilometers, 952 nautical miles), or $17^{\circ}$ east of the Moluccas Islands. The treaty did not clarify or modify the line of demarcation established by the Treaty of Tordesillas, and it did not validate Spain's claim to equal hemispheres $\left(180^{\circ}\right.$ each), so the two lines divided the Earth into unequal portions. Portugal obtained a larger portion, paying a compensation to Spain, who needed cash to fund its war against France. Under the treaty, Portugal gained control of all lands and seas west of the line, including all of Asia and its neighboring islands, leaving Spain with most of the Pacific Ocean. Although the Philippines was not mentioned in the treaty, Spain retained its claims to the archipelago, basing it right to them on their prior discovery by Magellan. By 1542, King Charles I had decided to colonize them, if Portugal would not protest too vigorously because the archipelago had no spices. Although he failed in his attempt, King Philip II succeeded in 1565, establishing the initial Spanish trading post at Manila.

During most of the XVI century, Portugal became the main controller of the spice trade, with strategic possessions all the way from Africa to Southeast Asia. That control was increasingly challenged by the Dutch and English, with the former becoming dominant at the beginning of the XVII century. During that period, the Spaniards also tried to participate in the exchanges with Asia opening up the Pacific route.

The expedition of Magellan was the first to reach the Philippines. It was there also that Magellan died. After his death, the survivors, in two ships, sailed on to the Moluccas and loaded with spice. One ship attempted, unsuccessfully, to return across the Pacific. The other ship, the Vittoria, continued west under the command of Juan Sebastián Elcano. The vessel sailed across the Indian Ocean, rounded the Cape of Good Hope, and arrived at the Spanish port of Sanlúcar de Barrameda on September 6, 1522, becoming the first ship to circumnavigate the globe. 
Juan Pablo Glasinovic Vernon

Revisting the Manila Galleon, a Chilean perspective from the XXI century

The second Pacific voyage was also made from Europe by the Spanish, shortly after Magellan's trip. A fleet of seven ships under the command of García Jofré de Loaysa sailed from La Coruña in July 1525; Elcano, as second-in-command and chief navigator, was with him. Loaysa lost three ships in the Strait of Magellan and entered the Pacific on May 26, 1526, with his four remaining vessels. Both Loaysa and Elcano died before the ships reached the Philippines. Only Andrés de Urdaneta and twenty other men survived to land in the Spice Island of Tidore, only to be taken prisoner by the Portuguese. He lived for 11 years in the Moluccas and he was fundamental in the colonization of the Philippines and the ManilaAcapulco route.

Hernán Cortés, the conqueror of Mexico, was informed from Spain of Loaysa's voyage. He thereupon sent an expedition of three ships under the command of Alvaro de Saavedra to reinforce his countrymen. Saavedra sailed on October 31, 1527, from Zihuatanejo, Mexico, on the first expedition organized from the American coast. Two of his ships were lost during a storm, but Saavedra reached Mindanao and then the Moluccas. He sailed from Tidore to return to New Spain (Mexico) in June 1528, but he could not find his way back. Thus, the first attempt to return to New Spain across the Pacific failed, Saavedra died at sea and the survivors had to go back to the Moluccas, where they were captured by the Portuguese and held in captivity for five years. In 1534, the surviving eight members of his crew made it back to Spain.

On November 1, 1542 a second expedition departed from Barra de Navidad, New Spain, in the American coast, with Ruy López de Villalobos in command. He reached Mindanao on February 2 of the following year, the first Spaniard to make explorations in that island. He bestowed upon these islands the name "Felipinas" in honor of the Crown-prince, Don Felipe of Spain, who later became King Felipe II. After two years of hardships and struggles, he was taken prisoner by the Portuguese and died at the Moluccas in 1546 .

\section{Spanish settlements in East Asia}

Although the Philippine archipelago was discovered in 1521, no European settlements were established there, so Luis de Velasco, the viceroy of New Spain, sent Miguel López de Legazpi to colonize it in 1564. He left Acapulco with five ships and reached Cebu, one of the southern islands of the archipelago, in April 1565, founding the first Spanish settlement on the site of modern Cebu City. Legazpi served as the first governor of the Philippines, from 1565 until his death. In 1570, he sent an expedition to the northern island of Luzon, arriving there himself the next year. After deposing a local Muslim ruler, he established the city of Manila on an existing settlement in 1571, which became the capital of the new Spanish colony and soon Spain's major trading port in East Asia. The Manila-Acapulco Galleon Trade started when Andrés de Urdaneta (who was Legazpi's pilot and who had been in the expedition of 1526) discovered a return route from Cebu to Mexico in 15651.

\footnotetext{
${ }^{1}$ This fact has been lately challenged with new studies by historians. According to Juan Gil in La Nao de China (1565-1815), navegación, comercio e intercambios culturales, the real discoverer of the return route was Juan Pablo de Carrión, a Spanish hidalgo who had been to the Philippines with Ruy López de Villalobos in 1542 and determined the itinerary followed by the Legazpi expedition.
} 


\section{At the crossroads of space and time: The conditions that made possible the Manila Galleon}

How a journey of around 15,000 kilometers (about 9,000 miles) each way, the world's longest navigation route, through a vast ocean with almost no land in between, became an artery of global trade? Several conditions converged and made possible this important and lasting trade route. In the first place, the location should be considered. Although the Philippines had no spices, which were the reason that pushed European expansion into the area, the archipelago was closer to a huge and dynamic market: China. The Chinese empire was the engine of a very active regional trade and the arrival of Spain sparked another scale of exchanges, connecting the markets all around the world like never. Therefore, Manila occupied a key position in East Asia at the end of the XVI century. From the north it received the Chinese silks and porcelain; from the south the cloves, the nutmeg and all the spices of the Moluccas; from the west came Indian cottons and ivory from Southeast Asia; and from the east (New Spain - Mexico) flowed silver coins with which to buy everything and redirect it to America.

Another element that explains the Manila Galleon is the irruption of the Americas (West Indies) as a new economic player, with a massive transfer of precious metals (silver and gold) into the world economy. That just happened when China did not have enough money to support the transactions of its flourishing economy (based on silver) ${ }^{2}$. In addition to appear as an abundant reserve of silver, the Americas soon became the sole supplier because Japan, who was the main source of silver for China in the second half of the XVI century, closed herself off from international trade in 1638, stopping the supply, reinforcing the crucial role of American silver as the pillar of economic production and global trade. With the mines of silver of Zacatecas in Mexico and from Potosí in Peru, the production would multiply by seven between 1572 and 1592. It is estimated that between 1500 and 1800, Hispanic America produced more than $80 \%$ of all the world's silver. The fleets of the Indies took most of this money to Sevilla to finance the expansion and maintenance of the Spanish empire, both in America and in Europe, but a third of this money found its way to China (Folch, 2013. P. 5).

By 1570, the silver/gold ratio was 12:1 in Mexico, while in China it was 4:1. The purchasing power of Mexican silver was thus multiplied by three when it met the Chinese market (Folch, 2013. p. 5). The traffic described inserted the Pacific region and the Americas into the world-economy, contributing to the monetization of the internal markets of China and India, and to the mass consumption of Asian silk and cotton; with this, it was perhaps the only axis of transcontinental scope that did not require the mediation of the Europeans, but it became a purely American contribution (Bonialian, 2012). For two and a half centuries, trade between China and the Americas flourished, contributing to improve the living standard of the American inhabitants by providing quality consumer goods at good prices, and China's economic and financial stability.

\footnotetext{
${ }^{2}$ In 1374, the Ming dynasty issued its first paper money (following similar initiatives from previous dinasties), known as Ta Ming T'ung Hsisng Pao Ch'ao ("Great Ming Precious Notes"). These notes were inconvertible to coin and little effort was made to maintain its value. Six different issues are known to have occurred between 1368-1426, although it is likely that there were many more. The value of these notes rapidly declined and by the early 15th century, the ratio between the paper and coin exceeded 300:1. The Great Ming Precious Notes eventually disappeared from commerce and there are no known references to paper money being in circulation after 1455 thus ending China's first 650 years of experience with paper money. For the next 500 years, China functioned under a silver economy that ended following Chiang Kai-shek's rise to power in 1927 and the formation of a Central Bank. At first silver came from China and the neibouring countries, but soon it was insufficient. At this point the Americas irrupted as a massive provider of silver.
} 
Juan Pablo Glasinovic Vernon

Revisting the Manila Galleon, a Chilean perspective from the XXI century

\section{Regulated trade: La ley se acata, pero no se cumple}

The historical peculiarity of Manila was at the same time the center where two unlimited demands converged, the Chinese silk in America and the American silver in China, and the point of contact of two administrations, the Chinese and the Spanish, equally engaged in applying restrictive measures to direct trade between the two (Folch, 2013, p. 11).

The Ming dynasty and then the Qing, never allowed the establishment of foreign traders and entrepreneurs in their territories, this only changed when European powers forced China, in the XIX century, to open up. In the case of Spain, under the Habsburg dynastic rule, they managed a very centralized empire with a heavily regulated trade, to benefit the metropolis and prevent the early autonomy of their dominions.

In order to limit both the number of Chinese products competing with the Spanish ones in the Mexican market and other American colonies, and the transfer of silver to China, the Galleon traffic was subject to an export quota, initially set at a value of 250,000 pesos in Manila, an amount important enough to maintain the Manila colony and small enough to be easily absorbed by Mexico. This authorized amount, which was always double the return trip, did not stop rising: 300,000 pesos in 1702, 500,000 in 1734, 750,000 in 1776 (Folch, 2013). However, these figures were always below the actual traffic, which doubled or tripled these values, amounting in fact between 1,500,000 and 3,000,000 pesos. The galleon Santísima Trinidad was captured in 1743 with more than twice the weight of those authorized (Folch, 2013). To further control the traffic, the route of the Galleon was limited to two ships per year - properties of the crown - and their load capacity was also established as a maximum capacity of $300 \mathrm{Tm}$ was decreed in 1593. But over the centuries and with the incentive to increase the load, its capacity was augmented, up to 1,000 tons in the XVII and 2,000 in the XVIII (Folch, 2013, p. 12).

From the beginning, the main beneficiaries were traders in New Spain, followed by their peers in Peru. Both constituted a powerful network, controlling the formal trade, but also a parallel traffic beyond the official supervision. At the end of the XVI century, the enormous profits that the Galleon brought to New Spain (Mexico) were enough motive for the viceroyalty to disrupt all attempts to establish a direct communication between Manila and Callao. Direct traffic from Peru to Manila would be repeatedly banned in 1593, 1595 and 1604 (Folch, 2013, p. 15). Shortly thereafter, traffic between Mexico and Peru would also be prohibited, with decrees that would be repeated in 1609, 1620, 1634, 1636 and 1706. But the ships of Lima never stopped arriving, either in the form of tolerated smuggling or fraud by intermediaries, despite the fact that the contrary currents and the winds made the trip from Acapulco to Callao longer and more dangerous than the one from Acapulco to Manila (Folch, 2013, p. 15).

Sometimes a large portion of the cargo was contraband and even though there were heavy penalties for carrying contraband (confiscation of the goods and four years chained to the oar of a galley for the offender), the rules were flagrantly violated, and bullion was routinely hidden in the cargo. To avoid taxes and other restrictions, merchants undervalued their goods on records and documents. Silk was the most important product that the Galleon brought to Mexico, also porcelain, cotton garments and furniture. The cargo from Acapulco to Manila was much less diversified: a little cochineal ${ }^{3}$, some cocoa, and a few

${ }^{3}$ An insect from tropical and sub tropical America from which the natural dye carmine is derived. 
barrels of wine in addition to the silver that filled the cellars. Ingots and heavy chests of coins were stored over the keel in the main hold, often the only ballast used for draft and stability (Folch, 2013, p. 17).

It must be considered that if the ships got through the route and the goods found their way to their destination, and the money or bartered goods found their way back, merchants often made profits between 100 and 300 percent (Facts and Details, 2015). Already in the XVI century, the Galleons of Manila reached to take 5 million pesos annually to the Philippines, where more than half ( 3 millions) were from the mines of Peru. Although extraordinary, in 1597, the Manila galleon exported the exorbitant sum of 12 million pesos, of which 8 million were metallic Andean (Bonialaran, 2017a). The drainage of Peruvian and New Spain metallic by the transpacific axis, despite all the efforts of the crown, subtracted resources from the transatlantic axis at the expense of the metropolis, also affecting gravely the financial situation of the Spanish Crown.

\section{Trade liberalization}

With the advent of a new dynasty in Spain in the early XVIII century, the House of Bourbon, many administrative changes and reforms came. In general terms, the Bourbons loosened regulations, opening up markets and ports to new traffic and competition. This coincided with the Spanish loss of hegemony in the Pacific, with English, Dutch and French ships actively trading and smuggling in the area.

By the last quarter of the century, the New Spain monopoly with Asia was broken with the establishment of a direct route between Spain and the Philippines. The first official license for this traffic was granted in 1776 to the Company of the Five Major Guilds of Madrid (Royal Order of June 12, 1776). In 1778, Charles III confirmed the opening of numerous ports, including Valparaíso and Concepción in Chile, Buenos Aires, Montevideo, Arica, Callao and Guayaquil.

Later on, the Royal Company of the Philippines received the exclusive right of direct trade with the Philippines and the rest of Asia from Spain and South America, although with a mandatory scale in Manila ${ }^{4}$. In each of the expeditions, the company could have a total of 500,000 pesos to acquire the necessary Asian goods for its turn, which meant the continuity of the structures of the Spanish-Asian trade of exchanging silver for oriental products. The company could navigate the route of Cape Horn, with stops in Montevideo and El Callao, or along the route of the Cape of Good Hope, with a stopover in the Isle of France and in Tranquebar (on the Coromandel coast in Southern India) but, very particularly, in Calcutta and Canton, before arriving in Manila, from where it was always necessary to return straight on the second route to avoid traffic from Asia to America (Martínez, 2016).

Competition weakened the Manila galleon and affected profits, so what was considered a highly profitable trade in a captive market, turned into an unpredictable business. The final coup was the independence of the Spanish colonies in America but mostly the changes of trade and production patterns, with the weakening of the Asian economies (India and China) and the emergence of industrial European and North American economies.

${ }_{4}^{4}$ According to the Royal Founding Certificate promulgated on March 10, 1785. 
Juan Pablo Glasinovic Vernon

Revisting the Manila Galleon, a Chilean perspective from the XXI century

\section{Chile and the Manila Galleon: Colonial trade}

Acknowledging that the main actors and beneficiaries of the Manila Galleon were the viceroyalties and the merchants of New Spain and Peru, Chile nonetheless benefited from this trade indirectly, as supplier of many goods to Peru. The profits made by Peruvian merchants with the Manila Galleon trade increased the purchasing power of the viceroyalty, stimulating further regional exchanges and local consumption of goods produced in other American colonies. However, and as stated previously, most of the activities related to the traffic of the Manila Galleon and its transshipment to Peru and to other locations were exercised clandestinely, under the cover of corruption, fraud and smuggling and therefore outside the documentary sources. For this reason, it is not possible to assess the real impact of that trade beyond the general circumstance mentioned above.

El Callao in Peru was the reception port for Chilean products and for the surrounding area. From there, a cabotage fleet called the "Armadilla del Mar del Sur", serviced trade to all ports up to Panama. The merchants of Lima controlled firmly all commercial routes in the South Pacific. In addition to Acapulco, they traded with Central America (mainly with Guatemala who became a cover for trade with Acapulco) and acquired goods in Portobelo (Panama), where the European merchandise arrived on Spanish ships. The imported items were brought to Lima and subsequently sold to the interior and the neighboring colonies. The Lima merchants, although already favored as middlemen by the monopolist regime enforced by the Spanish crown, did not cease to carry out operations related to contraband. Like the Mexican traders, they remained alert in defense of their interests, guarding them jealously for a long time (Suarez, 2016). Besides, Alto Peru (Bolivia) represented a huge consumer market where all types of merchandise could be placed. It was also a generous source of silver, so coveted by the Chinese and the mean of payment for the Manila Galleon trade.

During the XVI century, the Chilean economy was based on gold and silver, as it was in Peru. But this was short lived because most of the deposits were in areas re-conquered by Indian rebellions. Simultaneously, and due to the rapid expansion of the introduced cattle to the new territory, products such as charqui (dried meat), leather and tallow became the basis of the economic activity. The latter was the main export product, since it was used as raw material for the manufacture of candles. In this same period, tenancy of the land was transformed into the hacienda, which became the economic and social cornerstone of the colony for the next centuries. Chile found himself as the granary of Peru from 1680 onwards, due to a plague that ruined the Peruvian crops.

During the XVIII century, export of wheat was accompanied by important exports of tallow, wines and other products of agriculture and livestock, copper, rigging and wood. From Peru came sugar and tobacco (by far the most valuable), plus tocuyos, salt stones, wipes and clothes of Quito among others. To Río de la Plata, Chile exported copper artifacts as well as almonds and leather, while the imports consisted mainly of Yerba Mate from Paraguay. In both cases (Peru and Rio de la Plata), the exchange was deficitary for Chile. Nevertheless, this intercolonial trade allowed Chile the sale of most of his products, since with Spain the activity was limited to the shipment of raw materials and to the payment in gold and silver of the manufactures brought from the peninsula. Mining during the eighteenth century resurfaced, with silver and then gold as the main products. 
With the opening of the South Pacific to ships of other nations, and the increased importance of the Magellan Strait and the Cape Horn as the lanes linking the 2 oceans, Valparaíso acquired more relevance and was to shine in the XIX century, well after the end of the Manila Galleon. Concepción also increased its movement as a port serving the South of Chile and exporting to Peru and Alto Peru. In sum, Chile benefited from an active intercolonial trade, which in turn was strongly stimulated by the intercontinental exchange. It was soon evident that such a small economy was very dependent on the demand of other markets and, what was then true, is even more so today.

Considering at the anecdotal level our links with the West Pacific in colonial times, it is worth noting a rare case of a governor who served in Chile and the Philippines. Although there was a sort of career in which the best governors of the colonies close to the viceroyalties were later appointed viceroys (several Chilean governors became Peruvian viceroys), the posting to the Philippines of an American governor was rare. Francisco José de Ovando y Solís Rol de La Cerda, I Marqués de Ovando (1693 - 1755), was a sailor and Spanish colonial administrator who served, interim, as governor of Chile between June 1745 and March 1746, and as titular Governor General of the Philippines between 1750 and 1754 (Silos, 2005). In that condition he improved the local shipyards and ordered to build a galleon of 54 guns and 413 seats of crew, which was given the name of Santísima Trinidad y Nuestra Señora del Buen Fin, being completed in the year 1751.

The Santísima Trinidad was a Spanish galleon destined for merchant shipping between the Philippines and Mexico. It was the largest of the "Manila Galleons" and at the time was familiarly known as El Poderoso (The mighty). In August 1762 on its way towards Acapulco, the ship was captured by the Bristish and taken to Portsmouth, where it was sold. It is unknown what happened to the ship after the sale. The Governor Francisco José de Ovando y Solís Rol de La Cerda had no better luck, dying earlier on his way to New Spain (Mexico) in 1755, after ending his period.

\section{Conclusions: Revisiting the legacy of the Manila Galleon}

For more than 250 years, there was an active trade between Asia and the Americas. American silver fueled a spectacular development of the Asian economies and in particular of China, with mass production of silk and porcelain. What started as a transpacific trade of expensive luxury goods, shifted with time to include cheaper textiles and articles of current use in the colony accessible for the average population. This was the prelude of the industrial production of the XIX century and without doubt improved the life standard of the population in the Americas. But on the other hand, the abundance of precious metals, combined with colonial regulations, prevented our region to develop a relevant industrial base.

Furthermore, the Manila Galleon marked the introduction of the American continent into the global economy. This entry was constrained from the start by big asymmetries and, as mentioned, by strict regulations. These regulations stimulated contraband and fraud, on a very important scale, as it is possible to project taking into account many inconsistencies between what was declared at customs and the evidence of some captured galleons, the accounting books of Mexican and Peruvian merchants, and some seizures of the ships' cargo by the authorities, just to mention the most common cases detected by historians. Although it is not possible to set precisely the real volume of this trade, it can be safely said that it was much larger than what the official figures indicate (perhaps double) and therefore had a bigger 
Juan Pablo Glasinovic Vernon

Revisting the Manila Galleon, a Chilean perspective from the XXI century

impact and influence on consumption and trade pattern in the Americas, and in the exchanges of the latter with Asia and Europe.

In contrast with China, the Americas (and even Europe) did not have an interesting offer of products for that market at the time, but silver. On the other hand, Spain did not want her colonies to trade and produce freely, and always tried to maintain a colonial dependency on more elaborated items from the peninsula. This in part explains the pattern of trade of most of Latin American countries today, with commodities as their main exports. China, as stated earlier, tolerated trade, but never allowed foreigners, merchants or investors to set foot on her soil.

Beyond that economic dimension, there were deep influences and impacts on other areas such as culture, agriculture and diet, and even migration, many of them still not sufficiently studied or assimilated. As stated at the beginning, it was not the purpose of this article to explore in depth other aspects beyond trade, but it is a fact that the material culture of the Americas changed with the arrival of the Galleon's Asian products. New forms of artistic expression arose; this cultural influence is also seen in the language, the culinary customs, the dress and traditions. On the Asian side, the same happened with the adoption of crops like corn and potato that diminished dependency on rice as the main staple food. Chilies also became an essential ingredient in most of Asian cuisines.

The new commercial networks consolidated in the Modern Age with the Manila Galleon as an emblematic catalyst and based on the western demand of Asian products, allowed the continuous circulation of people, objects and ideas worldwide (Baena, 2013). I am optimistic that more about the rich legacy of the Manila Galleon will come to light in the following years, as both East Asia and the Americas are reassessing their relationship, looking out for common grounds and rediscovering that they had a special and unique relationship for almost 3 centuries.

Looking back at this extraordinary chapter of history, is there anything that persists till today or could be taken as inspiration for a new trade route or a new model of relationship between Asia and the Americas? The question is even more relevant when Asia Pacific is consolidating as the engine of global growth and at a time when China, its main actor, is pushing a new strategy of trade and investment through what is known as the OBOR Initiative (One Belt One Road), and that includes Latin America.

Today, as during the Manila Galleon period, China is central to that traffic as an exporter of manufactures. Another similarity is that China needs external resources in order to continue to develop. What it is different now is that Latin America has become an important source of commodities for producing those manufactures, in addition to a relevant supplier of food products for a huge market. Although the asymmetry persists (commodities $\mathrm{v} / \mathrm{s}$ manufactures), the exchange is more diversified, and it presents a whole range of opportunities, particularly in the field of investments, services and healthy food. If China, at the time of the Manila Galleon, tried to separate trade from other dimensions, impeding the establishment of foreigners on its soil and not venturing abroad, today it looks for a more comprehensive and bidirectional relationship. Another difference is the existence of a dense network of free trade agreements and other economic treaties (investment, exemption of double taxation, etc.) between most East Asian and Latin American countries. If the Manila Galleon was mainly a trade phenomenon (which as mentioned generated multiple consequences beyond the commercial field), the current relationship is undoubtedly more diverse and with more players. 
Considering the real possibility of the fragmentation of globalization as we have known it during the last decades, it is time to consider new schemes for the exchanges between Asia and Latin America. In that context, the Pacific Alliance is in a pole position to set up a new "route". Two of its members are the successors of the viceroyalties and potentially all of them can serve a vast hinterland towards the Pacific Ocean. Furthermore, two of the members have China as their main trading partner and a substantial share of their commerce with Asia. On the Asian side, ASEAN is also called to enrich this new relationship with its strong network of value-added chain. In an extended economic war between the United States and China, both sub regions, ASEAN and the Pacific Alliance, could become key platforms from where to do business with the giant economies.

Considering the Manila Galleon, perhaps the biggest lesson for today is not allowing our exchanges to be conditioned. In that sense, Chile and the other Pacific Alliance members are right to insist in deepening free trade, investments and people mobility, because as history has shown us, restrictions imposed upon us, contributed to maintain the asymmetries and thus inhibited our prosperity in favor of others. The challenges are enormous, but so are the benefits as Latin America can aim to recover a central place in the exchanges with Asia. For that purpose, we will have to go back to the spirit of those who made possible the Manila Galleon. We need to imbue ourselves with the ambition, bravery and determination of the conquistadors, explorers and merchants who, from nothing, created a global trade. The good news is that we share a unique chapter of history from where to start a second one.

\section{References}

Baena, A. (2013). Intercambios culturales y globalización a través del Galeón de Manila: comercio y producción de biombos (s. XVII y XVIII). In S. Berabéu (Ed.), La nao de China (1565-1815): navegación, comercio e intercambios culturales (pp. 213-245): Universidad de Sevilla.

Bernabéu, S. (2018). La Nao de China, 1565-1815, navegación, comercio e intercambios culturales, Editorial Universidad de Sevilla, 2018, ISBN e-book: 978-84-472-2145-5

Biblioteca Nacional de Chile. Cartas de Pedro de Valdivia. from http://www.memoriachilena.gob.cl/602/w3-channel.html

Biografía de Chile. Historia de Chile: Primer periodo: Construcción de una identidad mestiza. El Sistema Económico Colonial. from http:/ $/$ www.biografiadechile.cl/detalle.php?IdContenido=1592\&IdCategoria=93\&IdArea $=43$ 1 \&TituloPagina $=$ Historia $\% 20 \mathrm{de} \% 20$ Chile \&pos $=13$

Bonialian, M. (2017a). La bistoria económica del Pacífico en su larga duración. Una revisión a las Filipinas y el Pacifico de los ibéricos de Pierre Chaunu, Illes i imperis: Estudios de historia de las sociedades en el mundo colonial y post-colonial, ISSN 1575-0698, No. 19, págs. 77-99

Bonialian, M. (2017b). Comercio y atlantización del Pacifico mexicano y sudamericano la crisis del lago indiano y del Galeón de Manila, 1750-1821, América Latina en la Historia Económica, ISSN-e 1405-2253, Vol. 24, No. 1, 2017, págs. 7-36

Bonialian, M. (2012) El Pacifico hispanoamericano: politica y comercio en el imperio español (1680-1784), la centralidad de lo marginal, México, El Colegio de México-Colegio Internacional de Graduados entre Espacios, $490 \mathrm{pp}$.

Carrillo, R. (2014). Asia llega a América Migración e influencia cultural asiática en Nueva España (1565-1815), Asiadémica: revista universitaria de estudios sobre Asia Oriental, ISSN-e 2341-233X, No. 3, (Ejemplar dedicado a: Gener), págs. 81-98 
Juan Pablo Glasinovic Vernon

Revisting the Manila Galleon, a Chilean perspective from the XXI century

Castillo, M. (2015). Historia de las relaciones comerciales formativas de Chile con Perú. Orígenes coloniales y alborada de la Independencia, Eduardo Téllez y Germán Alburquerque (editores). Estud. int. (Santiago, en línea) [online]. Vol.47, n.182, ISSN 0719-3769.

Del Valle Pavón, G. (2005). Los mercaderes de México y la transgresión de los límites al comercio pacífico en Nueva España, 1550-1620, Revista de Historia Económica - Journal of Iberian and Latin American Economic History, ISSN 0212-6109, Año no 23, No Extra 1, págs. 213-240

Escudero, L. (2004). El galeón de Manila, Sociedad Geográfica Española, ISSN 1577-3531, Nº 19, págs. 24-29

Facts and Details. (2015). Spanish galleon trade between the Philippines and Mexico, Retrieved from: http://factsanddetails.com/southeast-asia/Philippines/sub5 6a/entry-3835.html

Folch, D. (abril de 2013). El galeón de Manila, Universitat Pompeu Fabra, Shanghai, Instituto Cervantes.

Heine, J. (2017). Recreando el Galeón de Manila: globalización y relaciones sino-latinoamericanas Estudios Internacionales - ISSN 0716-0240 • 225-251, Instituto de Estudios Internacionales Universidad de Chile

Hewitt, M. (2008). China's First Experience with Paper Money. from http://news.goldseek.com/GoldSeek/1216647867.php

Inostroza, L. (2013). La colonización minera y agrícola en la ciudad Imperial del Sur de Chile 1551-1561, Revista complutense de historia de América, ISSN 1132-8312, No 39, (Ejemplar dedicado a: Dossier: Relaciones internacionales, identidades colectivas y vida intelectual en América Latina (18101945)), págs. 107-127

Inostroza, L. (2015). El mercado regional de Concepción y su articulación comercial al virreinato del Perú, 1660-1690, Revista Espacio Regional, Vol. 2, N¹2, Osorno, julio-diciembre, pp.39-55

Latasa, P. \& Fariñas de Alba. (1991). El comercio triangular entre Filipinas, México y Perú a comienzos del siglo XVII, Revista de historia naval, ISSN 0212-467X, Año no 9, No 35, págs. 13-28

Los caminos de la plata. (2013). Un patrimonio común para las dos orillas. from http://loscaminosdelaplata.com/

Martínez, C. (2016). El Galeón de Manila y la economía filipina (1565-1815), Boletín económico de ICE, Información Comercial Española, ISSN 0214-8307, № 3074 (Del 1 al 30 de abril), (Ejemplar dedicado a: Filipinas en el siglo XXI), págs. 51-62

Milton, G. (2000). Nathaniel's nutmeg, Penguin, 2000, 400 ps, ISBN-10: 0140292608.

Munro, J. (1983). The Consumption of Spices and Their Costs in Late-Medieval and Early-Modern Europe: Luxuries or Necessities?

Pares. (2018). Portal de archivos españoles. from http://pares.mcu.es/

Peterson, A. (August, 2014). Making the first trade global route: the Southeast Asian foundations of the AcapulcoManila galleon trade 1519-1650, Dissertation submitted to the graduate division of the University of Hawaii at Manoa in partial in partial fulfillment of the requirements for the degree of Doctor of Philosophy in History.

Porras, J. (1993). El Galeón de Manila, Revista española del Pacífico, ISSN 1131-6284, Nº. 3, págs. 167176

University of Toronto. The Consumption of Spices and Their Costs in Late-Medieval and Early-Modern Europe: Luxuries or Necessities? from https://www.economics.utoronto.ca/munro5/SPICES1.htm

Silos, J. (2005). El viaje de 1755 del galeón Santísima Trinidad, Revista de historia naval, ISSN 0212-467x, Año $23 \mathrm{~N}^{\circ} 88$, págs. 57-82 
Latin American Journal of Trade Policy 3 (2019) - Universidad de Chile

Suárez, M. (2015). Sedas, rasos y damascos Lima y el cierre del comercio triangular con México y Manila en la primera mitad del siglo XV II, América Latina en la Historia Económica, ISSN-e 1405-2253, Vol. 22, No. 2 (mayo-agosto, 2015), págs. 101-134

Taboada, H. en Mariano Ardash Bonialian. (2015). El Pacifico hispanoamericano: politica y comercio en el imperio español (1680-1784), la centralidad de lo marginal. Estud. Asia Áfr., Ciudad de México, v.50, n.2, p. 510-518.

Yuste, C. (2007). Emporios transpacíficos. Comerciantes mexicanos en Manila, 1710-1815, México, UNAM. 